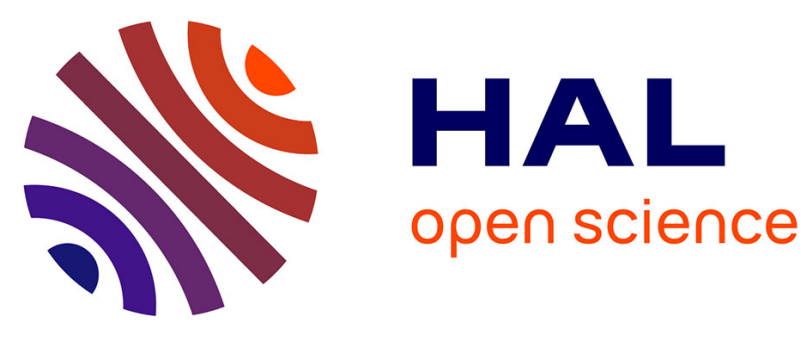

\title{
Interconnected place-based social-ecological research can inform global sustainability
}

Patricia Balvanera, Rafael Calderón-Contreras, Antonio J Castro, María R Felipe-Lucia, Ilse R Geijzendorffer, Sander Jacobs, Berta Martin-Lopez, Ugo Arbieu, Chinwe Ifejika Speranza, Bruno Locatelli, et al.

\section{To cite this version:}

Patricia Balvanera, Rafael Calderón-Contreras, Antonio J Castro, María R Felipe-Lucia, Ilse $\mathrm{R}$ Geijzendorffer, et al.. Interconnected place-based social-ecological research can inform global sustainability. Current Opinion in Environmental Sustainability, 2017, 29, pp.1-7. 10.1016/j.cosust.2017.09.005 . hal-01672041

\section{HAL Id: hal-01672041 \\ https://hal.science/hal-01672041}

Submitted on 22 May 2019

HAL is a multi-disciplinary open access archive for the deposit and dissemination of scientific research documents, whether they are published or not. The documents may come from teaching and research institutions in France or abroad, or from public or private research centers.
L'archive ouverte pluridisciplinaire HAL, est destinée au dépôt et à la diffusion de documents scientifiques de niveau recherche, publiés ou non, émanant des établissements d'enseignement et de recherche français ou étrangers, des laboratoires publics ou privés.

\section{(ㅇ)(1) $\$$}

Distributed under a Creative Commons Attribution - NonCommercial - NoDerivatives 44.0 


\section{Interconnected place-based social-ecological research can inform global sustainability}

Patricia Balvanera ${ }^{1}$, Rafael Calderón-Contreras ${ }^{2}$, Antonio J Castro ${ }^{3,4}$, María R Felipe-Lucia ${ }^{5}$, Ilse R Geijzendorffer ${ }^{6}$, Sander Jacobs ${ }^{7,8}$, Berta Martín-López ${ }^{9}$, Ugo Arbieu ${ }^{10}$, Chinwe Ifejika Speranza $^{11}$, Bruno Locatelli ${ }^{12,13}$, Natalia Pérez Harguindeguy ${ }^{14}$, Ilse Ruiz Mercado ${ }^{1}$, Marja J Spierenburg ${ }^{15}$, Améline Vallet ${ }^{16}$, Laura Lynes ${ }^{17}$ and Lindsey Gillson ${ }^{18}$

\section{Addresses}

${ }^{1}$ Instituto de Investigaciones en Ecosistemas y Sustentabilidad, Universidad Nacional Autónoma de México, Morelia, Michoacán, Mexico

${ }^{2}$ Departamento de Ciencias Sociales, Universidad Autónoma Metropolitana Unidad Cuajimalpa, Mexico City, Mexico

${ }^{3}$ Idaho State University, Department of Biological Sciences, Social-Ecological Research lab, 921 South 8th Avenue, Pocatello, ID 83209, United States

${ }^{4}$ Centro Andaluz para la Evaluación y Seguimiento del Cambio Global (CAESCG), Departamento de Biología Vegetal y Ecología, Universidad de Almería, La Cañada de San Urbano, 04120 Almería, Spain

${ }^{5}$ Institute of Plant Sciences, University of Bern, Altenbergrain 21, 3013 Bern, Switzerland

${ }^{6}$ Tour du Valat, Research Institute for the conservation of Mediterranean Wetlands, Le Sambuc, 13200 Arles, France

${ }^{7}$ Research Group Nature and Society, Research Institute for Nature and Forest (INBO), Kliniekstraat 25, 1070 Brussels, Belgium

${ }^{8}$ Belgian Biodiversity Platform (BBPF), Avenue Louise 231, 1050 Brussels, Belgium

${ }^{9}$ Leuphana University of Lüneburg, Faculty of Sustainability, Institute of Ethics and Transdisciplinary Sustainability Research, Scharnhorststraße 1, 21355 Lüneburg, Germany

${ }^{10}$ Senckenberg Biodiversity and Climate Research Centre (BiK-F), Senckenberganlage 25, 60325, Frankfurt am Main, Germany

${ }^{11}$ Institute of Geography, University of Bern, Switzerland

${ }^{12}$ Agricultural Research for Development (CIRAD), Montpellier, France

${ }^{13}$ Center for International Forestry Research (CIFOR), Lima, Peru

${ }^{14}$ Multidisciplinary Institute of Plant Sciences \& Faculty of Exact, Physic and Natural Sciences (CONICET-UNC), Córdoba, Argentina

${ }^{15}$ Radboud University Nijmegen, Department of Anthropology and Development Studies, P.O. Box 9104, 6500 HE Nijmegen, the Netherlands

${ }^{16}$ CIRED, AgroParisTech, CIRAD, Paris, France

${ }^{17}$ The Rockies Institute, Canmore Alberta, Canada

${ }^{18}$ African Climate and Development Initiative, South Africa

Manuscript published in Current Opinion in Environmental Sustainability:

Balvanera, P., R. Calderón-Contreras, A. J. Castro, M. R. Felipe-Lucia, I. R. Geijzendorffer, S. Jacobs, B. Martín-López, U. Arbieu, C. I. Speranza, B. Locatelli, N. P. Harguindeguy, I. R. Mercado, M. J. Spierenburg, A. Vallet, L. Lynes, and L. Gillson. 2017. Interconnected placebased social-ecological research can inform global sustainability. Current Opinion in Environmental Sustainability 29:1-7. doi:10.1016/j.cosust.2017.09.005 


\begin{abstract}
Global sustainability initiatives are gaining momentum and impact, and place-based research can provide complementary insights to strengthen them. Here, we explore the current and potential role of place-based research into informing global sustainability initiatives by assessing the strengths, challenges, and opportunities. We show that place-based research allows for a better understanding of global social-ecological dynamics, and that transformations towards sustainability are often triggered at the local scale through the co-construction of local solutions. We discuss that the very nature of place-based research can hinder its transferability because its global integration faces temporal, spatial and governance scale mismatches, and we identify some of the key challenges of scaling-up its findings. We highlight new opportunities to mainstream place-based research that are emerging from first, long-term networks of place-based research, second, new institutional research settings that contribute with conceptual comprehensive frameworks and capacity building tools, third, a global community of practice, and fourth, the concept of region as a bridge between local and global sustainability initiatives. We believe that the time is ripe to promote the role of place-based social-ecological research as a key contributor to achieve global sustainability goals.
\end{abstract}

\title{
Graphical abstract
}

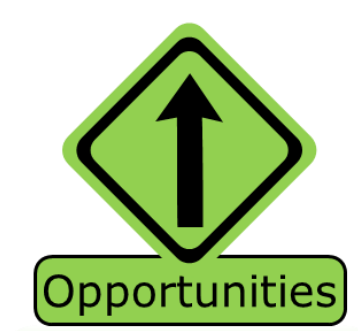

Networks of placebased long-term research

Conceptual frameworks

Training \& communication

Global community of practice

Regions for linking global \& local

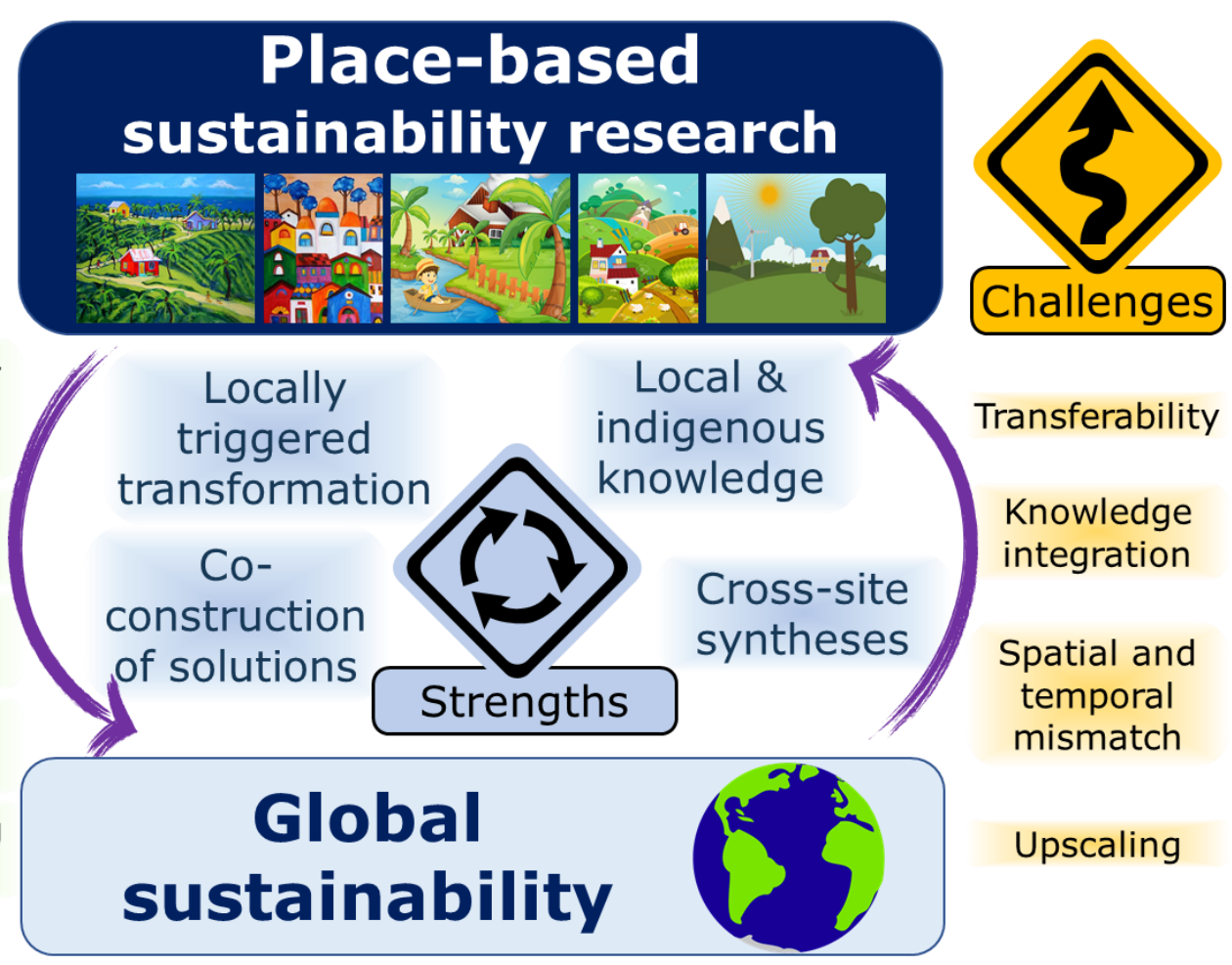




\section{Introduction}

Global sustainability initiatives have increasingly been addressed by global top-down initiatives, but the abundant and diverse bottom-up initiatives should be urgently acknowledged [1*]. The global biodiversity outlook (GBO) is just one of the many multi-national research, monitoring, or synthesis enterprises that contribute significantly towards informing the global sustainability agenda. Whilst cross-scale linkages within social-ecological systems are at the core of the search for sustainability, solutions towards sustainability are context-specific [2], and relatively little insights from place-based social-ecological research are currently being used to inform and inspire global sustainability research. For instance, extensive work has been done on the development of locally relevant future scenarios [3*], and yet global scale scenarios provide only very rough simplifications of contrasting social-ecological alternatives [4].

Place-based research addresses the particularities of specific landscapes, seascapes or transitional zones as dynamic social-ecological systems [5*]. A place (e.g. Mexico City) or a region (e.g. Sub-Saharan Africa) is not only a territorially bounded spatial unit with features that make it unique or distinguishable from other areas, but it is also where social, economic and political influences converge, as well as where multiple biophysical and societal flows and networks meet [6-8]. Place-based social-ecological research, aimed at understanding how social-ecological systems evolve over time and respond to policy interventions through the exchange of knowledge across disciplinary boundaries and among different stakeholders to address sustainability challenges at a particular place $\left[5^{*}, 9^{*}, 10^{*}\right]$, is uniquely positioned to explore the interplay between the local and the global scales, by recognizing the distinctiveness of local entities, while addressing the impacts of global dynamics from them [11**].

Scaling up of local insights and successful initiatives into global sustainability research is underway. Initiatives such as the 'Good Anthropocene' project [12] are aimed at identifying the multiple new strategies developed towards creating a more just, prosperous, and ecologically diverse world developed by numerous individuals, organizations, and political leaders, to sustain and amplify these efforts towards achieving large-scale transformations. Yet, much more is needed. In this paper, we explore the current and potential role of place-based social-ecological research into informing the global sustainability scientific and policy agendas by assessing its strengths, challenges and opportunities. 


\section{Strengths}

Place-based social-ecological research allows for a better understanding of the linkages between global and local sustainability

It explores how micro-processes (e.g. exchanges between individuals) scale-up, how macroprocesses (e.g. global market streams) scale down, and how local social-ecological systems interact with each other, by focusing on interactions across scales, and on the identification of fast and slow drivers of social and ecological change, thresholds, traps and time lags [11**,13]. Insights on global impacts of widespread localized groundwater depletion from the in-depth exploration of a few contrasting cases [13], as well as efforts to refine the spatial resolution of climate models at local scales by incorporating indigenous knowledge on changing climate [14], emerge from place-based research. While top-down approaches can propose theoretical pathways, only comparisons across sites [5*] can allow to explore how actual local insights and are needed to achieve sustainability at a global scale.

\section{Transformations towards sustainability are often triggered at the local scale}

Local social-ecological experiences, including conflicts [15] as well as initiatives that foster equity and sustainability [12] can be used to identify useful tools and lessons for global environmental governance [16]. While specific solutions are not scalable per se [17], the lessons learned from their implementation and specifically from the interactions among local stakeholders can be scaled up to delineate pathways towards sustainability transformations [12]. Also, the uptake of these lessons can occur at a range of scales, ranging from individuals to multilateral agreements [18]. Insights from place-based research allows for changing values that hinder the achievement of global sustainability goals, and for inspiring alternative development pathways and practices for the future [12].

\section{Place-based research fosters the co-construction of solutions}

A genuine local problem, worth addressing, worth solving by a wide range of actors (e.g. researchers, businesses, government and the civil society) provides a unique opportunity to engage different perspectives (e.g. land-scape management, cultural significance), disciplines (e.g. ecology, economics or political sciences) and knowledge systems (e.g. indigenous and local knowledge, scientific or technical knowledge) [9*,19]. The attachment to a 'place' and the objective of finding solutions can foster the involvement of the different actors, as well as ensure academic quality and local pertinence of the research [20,21]. The resulting co-produced knowledge is more likely to be useful and acceptable than knowledge produced only by one type of stakeholder [22] or by top-down (e.g. developed by governments) directives [23].Place-based research renders the important contribution of indigenous and local knowledge visible Biocultural diversity plays a key role in the resilience of social-ecological systems [24,25]. Local communities who depend on natural resources have developed practices, institutions, and knowledge to adapt to social and environ- mental changes [26], and many of them hold precious knowledge of how biological and cultural diversity can enhance the ability of societies to cope with present and future global changes [27]. While the longevity of many traditional management practices is a testament to their ability to adapt to changing environmental and social conditions, as well as to their local suitability, some of these practices can be highly unsustainable or lead to unpredicted and undesired outcomes [28]. 


\section{Challenges}

\section{The very nature of place-based research can hinder its transferability}

Place-based research develops around locally relevant issues, which vary among socialecological contexts. Instead, global sustainability issues are those that are common across multiple places and contexts, or those that are made visible by more influential or interconnected stakeholders, or by global bodies. This means that local issues may not relevant at global scales, or just not been explicitly integrated into global discourses. Views on what constitutes a relevant issue or a solution are strongly dependent on knowledge derived from direct experiences [29]. Local narratives associated with analogous issues can radically differ within and among sites hindering their integration into global discourses, as is the case of contrasting views on the impacts of large carnivores on people's livelihoods in different continents [30-32]. Additionally, transferability across sites can be hindered by communication barriers. Insights gained in a specific context may not be easily transferred to larger scales due to stark contrasts in world views, perceptions, or needs, including different languages and dialects. For example, when place-based research findings on fire management in Alaska contradicted national policy narratives, results from place-based science were questioned [33].

\section{The integration of different knowledge systems into place-based research is both a strength and a challenge}

An evidence-based approach that allows for the integration of different knowledge systems is increasingly seen as key to more resilient governance [34,35]. Yet, the credibility of indigenous and local knowledge by national or international actors is still an issue in some arenas [36]. It is particularly challenging to transfer place-based knowledge that is culturally sensitive and even sacred, such as that from indigenous communities that may mistrust the use of their knowledge by 'outsiders' [37]. The co-production of knowledge inherent to place-based research can limit the transferability of its outcomes, because it often requires capacity building and long-term involvement of multiple actors. Co-production of knowledge also poses the question of whose voices must be included in outreach strategies and science-policy interface [38,39], and requires developing mechanisms to leverage power imbalances [40,41].

\section{Global integration of place-based sustainability research faces mismatches in spatial and temporal scales}

It takes time for local issues to be globally recognized, as is the case of the increasing degradation of African savannahs due to bush encroachment [42]. Further, the local implementation of solutions, such as local interventions to address degraded soils, can take a long time to show impacts at larger scales than local [43]. Also, global drivers have different impacts in different local contexts, leading to very different responses at local scales. For instance, climate change can lead to increasing precipitation in some areas and increasing drought in others, and a variety of responses that are implemented and transmitted at local or regional scales are being developed [14,34].

\section{Upscaling place-based research faces several methodological challenges}

First, identifying the systems' boundaries faces some methodological challenges because they depend on the problem to be addressed and the scales associated to it [44-46]. Second, mobilizing data from multiple case studies to perform cross-site assessments requires tailoring 
research protocols to each specific case study, and particular research team [10*]. This challenge requires an adaptation of research methods [5*] to ensure the integration of local insights into the co-production of knowledge [47]. Third, scaling up insights gained from place-based socialecological research is dependent on new theoretical frameworks that will advance our understanding of how to assess multi-scale dynamics [48]. Fourth, more research is needed on why, when, and how can insights from a particular place and context be exported to other analogous scales, or scaled up at larger spatial or institutional and governance scales. Fifth, the actual upscaling of successful initiatives developed from place-based research, such as the development of participatory monitoring schemes, can be hindered by how much relevant stakeholders are willing to be involved in them [49].

\section{Opportunities}

Networks of place-based long-term social-ecological transdisciplinary teams are critical to inform the global sustainability scientific and political agendas

Understanding the local complexity of each social-ecological system, as well as the variability across contexts of these systems, can inform the search for pathways towards sustainability $\left[5^{*}, 50,51\right]$. By establishing a network of transdisciplinary research teams, the complex dynamics of socio-ecological systems can be further unraveled from the identification of key processes that operate across sites, the context dependent interactions among them, as well as commonalities and specificities of the alternatives identified among places facing similar sustainability issues $\left[10^{*}, 12,45,52\right]$. The long-term monitoring of the dynamics of social-ecological systems and the co-generation of alternatives, is needed to identify the occurrence and consequences of unusual, extreme or critical events [20]. Also, syntheses across place-based social-ecological research sites can inform, for example, key features for more successful place-based social-ecological sustainability research $\left[10^{*}\right]$, or the potential impacts of participatory scenario planning [3*].

New research initiatives and new institutional settings can foster the integration of placebased research insights into global sustainability research and policy agendas

Research networks (Table 1) such as the Program for Ecosystem Change and Society [11**] and the Knowledge Action Networks of Future Earth [53] are already mainstreaming place-based research into global sustainability initiatives. Similarly, global scale science-policy initiatives are synthesizing results from place-based research by promoting and facilitating communicating among scientists, managers and stakeholders on sustainability issues (Table 1). 


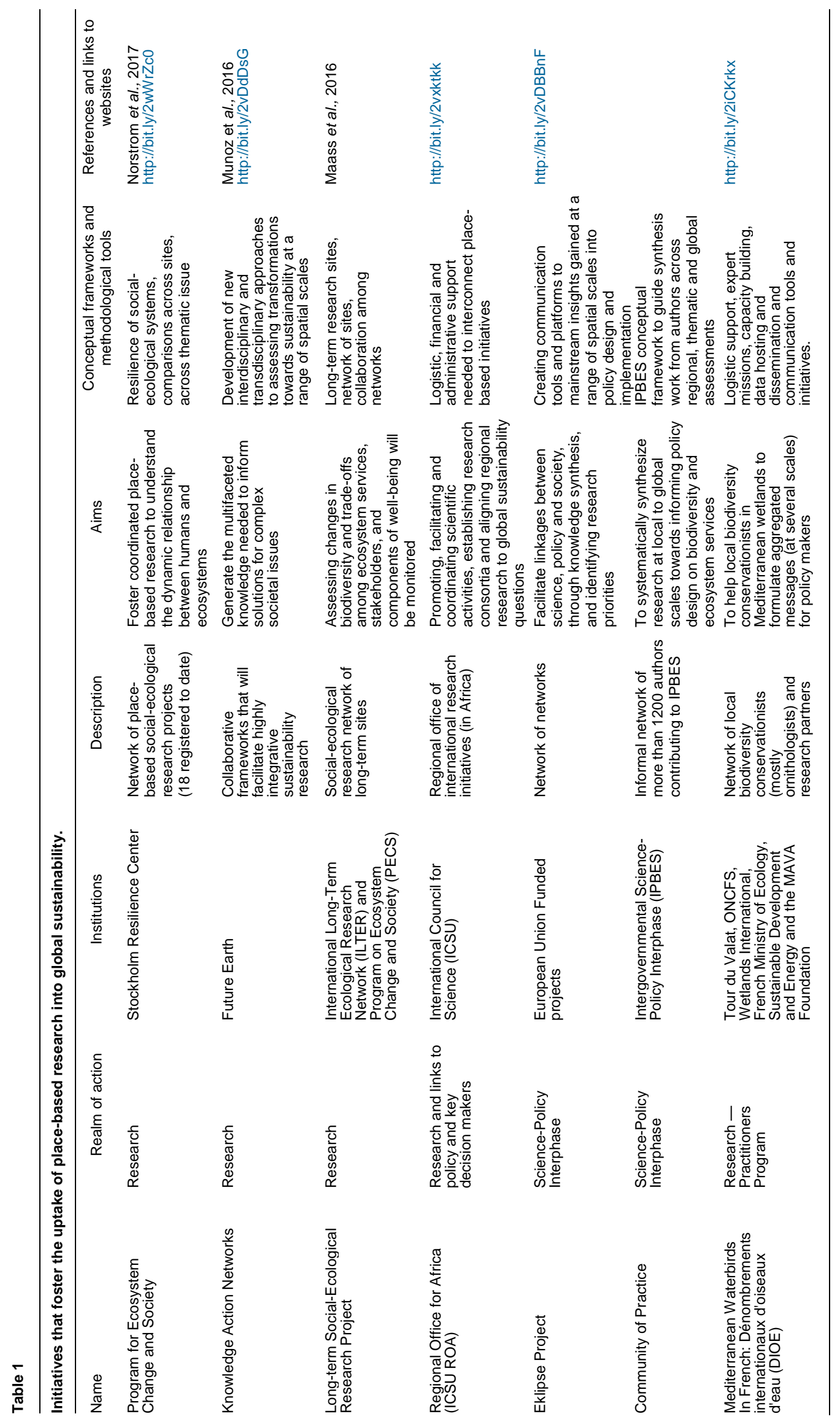


New conceptual frameworks are increasingly available to foster the uptake of place-based research insights into global sustainability initiatives

Complexity thinking has been shown to foster the integration of researchers and stakeholders through participative planning and adaptive decision-making process [52]. The 'telecoupling' framework [17] illustrates the increasing geographic scales of interactions between distant local places. The 'land system archetypes' concept allows assessing the transferability of place-based research to other geographical areas [54]. Planetary and regional boundaries, in terms of safe and just social- ecological spaces [55,56], are increasingly operationalized at local scales and feeding back into global narratives [55]. The Intergovernmental Platform of Biodiversity and Ecosystem Services (IPBES) assessment and valuation guidelines stress the importance of including multiple worldviews and value systems, explicitly requiring complementary knowledge from indigenous and local communities and practices alongside classic scientific data [40].

Place-based participatory scenarios can be integrated into global models in the search for pathways towards sustainability

Participatory scenario planning allows the identification of shared objectives between the local actors and researchers, building common understandings and fostering learning [3*]. A coordinated set of locally based scenarios can be linked to global scale scenarios and narratives to inform global sustainability policies $\left[57^{*}, 58\right]$. The consideration of alternative futures and the dynamics of the relationships within a range of social-ecological systems in space and time can be used to avoid undesirable futures, and to better inform how local socialecological dynamics are likely to be reshaped by local and global drivers [57*].

\section{New capacity-building opportunities and communication tools are available}

Transdisciplinary courses are providing new generations with the conceptual and methodological tools to mainstream place-based research into global sustainability agendas, such as those at Alternet (http://bit.ly/ 242XInh), td-net (http://bit.ly/2wd5IY1), or the National University of Mexico (http://bit.ly/2fOgGMn). New tools of virtual communication and training that are supportive to up-scale the insights at local scale include newsletters, blogs, webinars, you-tube videos, online meetings, and live-chats to communicate distant communities and reach broad and diverse audiences (e.g. Www. stockholmresilience.org, www.ipbes.net). Leaflets, radio programs, and travel exchanges allow sharing insights among different stakeholders operating at different scales (e.g. http://bit.ly/2wd3lnN or exhibitions).

A global community of practice for place-based sustainability research is rapidly growing The construction of Communities of Practice at different scales, in which local communities, practitioners, decision makers, and researchers share expertise and visions to co-produce relevant knowledge and to nurture governance systems can significantly contribute to mobilize sustainability expertise across scales [59]. Communities of Practice foster reflexivity, collaboration, negotiation, integration, and innovation [59] and can legitimize the coproduced knowledge promoting its dissemination over many territories and through time [60]. 


\section{The regional scale provides a potential conceptual bridge between local place-based research findings and global sustainability questions}

By using regions (e.g. Sub-Saharan Africa), global sustainability questions can be downscaled to local places [61]. Whilst place-based research can be scaled up to the respective regional levels into policy design and implementation alternatives, regional questions can be down- scaled to local places. In this way, transdisciplinary approaches transcend the local scale and seek political support through deliberations and negotiations between science and society at various levels and between the different societies of the world, as is the case of Reducing Emissions from Deforestation and Forest Degradation (REDD+) pilot schemes [62].

\section{Conclusions}

Place-based and global sustainability insights have been developing in parallel and integration of and synergies between these processes should be stimulated. Placebased, long-term socialecological research can uniquely advance global sustainability initiatives by generating locally relevant knowledge and solutions in a globally determined context. Whilst these cannot be directly scaled-up, lessons learned across contexts can be synthesized by using common research protocols, such as those targeted at systematically assessing lessons learned from locally developed solutions or future scenarios, at comparing key drivers that shape the dynamics of social ecological systems across scales. Insights gained from a variety of sources and context can then be mainstreamed into the global sustainability agenda through their incorporation into global synthesis initiatives such as the regional, thematic or global assessments of IPBES.

The time is ripe for developing a global network of place-based sustainability research and practice initiatives, and tools to achieve this are now available. Given the magnitude of the planetary challenges we face today, we urgently need intense collaboration within the large but scattered community of scientists and practitioners. A stronger link between place-based and global scale initiatives is needed. These are preconditions to significantly advance global sustainability thinking as well as place-based action.

\section{Acknowledgements}

The main ideas for this paper were developed during the First Open Science Conference of the Program for Ecosystem Change and Society (PECS): http://www.pecs-science.org/. Patricia Balvanera acknowledges support from the Red Temática de Socioecosistemas y Sustentabilidad CONACYT, Antonio Castro was partially funded by the NSF Idaho EPSCoR Program and by the National Science Foundation under award number IIA-1301792 and the Andalusian Government (Project GLOCHARID). We thank two anonymous reviewers for insightful comments. 


\section{References}

Papers of particular interest, published within the period of review, have been highlighted as:

$*$ of special interest

** of outstanding interest

*1. Mooney H: Editorial overview: Sustainability science: social-environmental systems (SES) research: how the field has developed and what we have learned for future efforts. Current Opinion in Environmental Sustainability 2016, 19:v-xii.

Opening paper of a special issue of this journal on a range of research initatives on social-environmental systems, considering their current and future contributions to global sustainability

2. Ostrom E: A diagnostic approach for going beyond panaceas. Proceedings of the National Academy of Sciences 2007, 104:15181-15187.

*3. Oteros-Rozas E, Ravera F, Palomo I: Participatory scenario planning in place-based social-ecological research: insights and experiences from 23 case studies. Ecology and Society 2015.

Example of key tools used within place-based research and how to synthesize insights across case studies.

4. Nakicenovic N, Swart R (Ed): UK: Cambridge University Press; 2000.

*5. Carpenter SR, Folke C, Norström A, Olsson O, Schultz L, Agarwal B, Balvanera P, Campbell B, Castilla JC, Cramer W: Program on ecosystem change and society: an international research strategy for integrated social-ecological systems. Current Opinion in Environmental Sustainability 2012, 4:134-138.

Paper presenting the aims and approaches of the Programme on Ecosystem Change that promotes coordinated placebased social-ecological research.

6. Jonas AEG: Region and place : Regionalism in question. Prog Hum Geogr 2012, 36:263.

7. Allen J, Cochrane A: Beyond the territorial fix: regional assemblages, politics and power. Regional studies 2007, 41:1161-1175.

8. Paasi A: Region and place: regional identity in question. Progress in human geography 2003, 27:475-485.

*9. Fischer J, Sherren K, Hanspach J: Place, case and process: Applying ecology to sustainable development. Basic and applied ecology 2014, 15:187-193.

Presents important definitions and examples to understand the scope, relevance and approach of place-based research

*10. Balvanera P, Daw TM, Gardner TA, Martín-López B, Norström AV, Ifejika C, Spierenburg M, Bennett EM, Farfan M, Hamann M: Key features for more successful place-based sustainability research on socialecological systems: a Programme on Ecosystem Change and Society (PECS) perspective. Ecology and Society 2017, 22.

Synthesis of lessons learned from place-based social-ecological research from the perspective of the PECS community including conceptual, methodological and management tools.

**11. Norström A, Balvanera P, Spierenburg M, Bouamrane M: Programme on Ecosystem Change and Society: Knowledge for sustainable stewardship of social-ecological systems. Ecology and Society 2017, 22.

Opening paper of a special issue on the work by the Programme on Ecosystem Change and Society highlighting the different ways in which place-based social ecological research can contribute towards global sustainability

12. Bennett EM, Solan M, Biggs R, McPhearson T, Norström AV, Olsson P, Pereira L, Peterson GD, Raudsepp-Hearne C, Biermann F: Bright spots: seeds of a good Anthropocene. Frontiers in Ecology and the Environment 2016, 14:441-448.

13. Wilbanks TJ, Kates RW: Global change in local places. Environment: Science and Policy for Sustainable Development 1999, 43:601-628.

14. Fernandez-Llamazares F, Amaral Garcia R, Diaz-Reviriego I, Cabeza M, Pyhala A, Reyes-Garcia V: An empirically tested overlap between indigenous and scientific knowledge of a changing climate in Bolivian Amazonia. Regional Environmental Change 2017.

15. Martinez-Alier J, Temper L, Del Bene D, Scheidel A: Is there a global environmental justice movement? The Journal of Peasant Studies 2016, 43:731-755.

16. Biermann F, Abbott K, Andresen S, Bäckstrand K, Bernstein S, Betsill MM, Bulkeley H, Cashore B, Clapp J, Folke C, et al.: Transforming governance and institutions for global sustainability: key insights from the Earth System Governance Project. Current Opinion in Environmental Sustainability 2012, 4:51-60.

17. Liu J, Mooney H, Hull V, Davis SJ, Gaskell J, Hertel T, Lubchenco J, Seto KC, Gleick P, Kremen C: Systems integration for global sustainability. Science 2015, 347:1258832. 
18. Cash DW, Moser SC: Linking global and local scales: designing dynamic assessment and management processes. Global environmental change 2000, 10:109-120.

19. Wu J: Landscape sustainability science: ecosystem services and human well-being in changing landscapes. Landscape ecology 2013, 28:999.

20. Billick I, Price MV: The ecology of place: contributions of place-based research to ecological understanding: University of Chicago Press; 2010.

21. Vaughan HH, Waide RB, Maass JM, Ezcurra E: Developing and delivering scientific information in response to emerging needs. Frontiers in Ecology and the Environment 2007, 5:1-4.

22. Cash DW, Clark WC, Alcock F, Dickson NM, Eckley N, Guston DH, Jäger J, Mitchell RB: Knowledge systems for sustainable development. Proceedings of the National Academy of Sciences 2003, 100:8086-8091.

23. Bellefontaine T, Wisener R: The Evaluation of Place-Based Approaches. Policy Horizons Canada 2011.

24. Gómez-Baggethun E, Corbera E, Reyes-García V: Traditional ecological knowledge and global environmental change: research findings and policy implications. Ecology and society: a journal of integrative science for resilience and sustainability 2013, 18.

25. Ruiz-Mallén I, Corbera E: Community-based conservation and traditional ecological knowledge: implications for social-ecological resilience. Ecology and Society 2013, 18.

26. Folke C, Colding J, Berkes F: Synthesis: building resilience and adaptive capacity in social-ecological systems. Navigating social-ecological systems: Building resilience for complexity and change 2003, 9:352387.

27. Toledo V: Ecología, espiritualidad y conocimiento. De la sociedad del riesgo a la sociedad sustentable. México. Universidad Iberoamericana, PNUMA, Grupo Editorial Formato 2003.

28. Cáceres DM, Silvetti F, Díaz S: The rocky path from policy-relevant science to policy implementation - a case study from the South American Chaco. Current Opinion in Environmental Sustainability 2016, 19:57-66.

29. Abbott D, Wilson G: Exploring the Lived Experience of Climate Change. In The Lived Experience of Climate Change: Knowledge, Science and Public Action. Edited by: Springer International Publishing; 2015:27-50.

30. Dressel S, Sandström C, Ericsson G: A meta-analysis of studies on attitudes toward bears and wolves across Europe 1976-2012. Conservation Biology 2015, 29:565-574.

31. Inskip C, Carter N, Riley S, Roberts T, MacMillan D: Toward Human-Carnivore Coexistence: Understanding Tolerance for Tigers in Bangladesh. PloS one 2016, 11:e0145913.

32. Williams CK, Ericsson G, Heberlein TA: A quantitative summary of attitudes toward wolves and their reintroduction (1972-2000). Wildlife Society Bulletin 2002:575-584.

33. Ray L, Kolden C, Chapin III F: A case for developing place-based fire management strategies from traditional ecological knowledge. Ecology and Society 2012, 17.

34. Tengö M, Brondizio ES, Elmqvist T, Malmer P, Spierenburg M: Connecting diverse knowledge systems for enhanced ecosystem governance: the multiple evidence base approach. Ambio 2014, 43:579.

35. Tengö M, Hill R, Malmer P, Raymond CM, Spierenburg M, Danielsen F, Elmqvist T, Folke C: Weaving knowledge systems in IPBES, CBD and beyond-lessons learned for sustainability. Current Opinion in Environmental Sustainability 2017, 26:17-25.

36. Cash D, Adger WN, Berkes F, Garden P, Lebel L, Olsson P, Pritchard L, Young O: Scale and cross-scale dynamics: governance and information in a multilevel world. Ecology and society 2006, 11.

37. Shepherd RP, Persad K: Place-based Evaluation in a First Nations Context: Something Old, Nothing New, Often Borrowed, and Frequently Blue: Policy Horizons Canada; 2011.

38. Lopez-Rodriguez, Castro AJ, Cabello J, Jorreto S, Castro H: Science-policy interface approach for dealing with water environmental problems. Environmental Science and Policy 2015, 50:1-14.

39. Berbés-Blázquez M, González JA, Pascual U: Towards an ecosystem services approach that addresses social power relations. Current Opinion in Environmental Sustainability 2015, 19:134-143.

40. Pascual U, Balvanera P, Díaz S, Pataki G, Roth E, Stenseke M, Watson RT, Dessane EB, Islar M, Kelemen E, et al.: Valuing nature's contributions to people: the IPBES approach. Current Opinion in Environmental Sustainability 2017, 26:7-16.

41. Werlen B: Global Sustainability: Cultural Perspectives and Challenges for Transdisciplinary Integrated Research. Cham: Springer International Publishing; 2015.

42. O'Connor TG, Puttick JR, Hoffman MT: Bush encroachment in southern Africa: changes and causes. African Journal of Range \& Forage Science 2014, 31:67-88.

43. Liu J, Dietz T, Carpenter SR, Alberti M, Folke C, Moran E, Pell AN, Deadman P, Kratz T, Lubchenco J: Complexity of coupled human and natural systems. science 2007, 317:1513-1516. 
44. Castellarini F, Siebe C, Lazos E, de la Tejera B, Cotler H, Pacheco C, Boege E, Moreno AR, Saldívar A, Larrazábal A: A social-ecological spatial framework for policy design towards sustainability: Mexico as a study case. Investigación ambiental Ciencia y política pública 2015, 6.

45. Martín-López B, Palomo I, García-Llorente M, Iniesta-Arandía I, Castro AJ, Gómez-Baggethun E, Montes C, , : Delineating boundaries of social-ecological systems for landscape planning: A comprehensive spatial approach. Land Use Policy 2017, 66:90-104.

46. Hamann M, Biggs R, Reyers B: Mapping social-ecological systems: Identifying 'green-loop' and 'red-loop' dynamics based on characteristic bundles of ecosystem service use. Global Environmental Change 2015, 34:218-226.

47. McNutt K: Public engagement in the Web 2.0 era: Social collaborative technologies in a public sector context. Canadian Public Administration 2014, 57:49-70.

*48. Scholes RJ, Reyers B, Biggs R, Spierenburg MJ, Duriappah A: Multi-scale and cross-scale assessments of social-ecological systems and their ecosystem services. Current Opinion in Environmental Sustainability 2013, 5:16-25.

Provides conceptual and methodological tools to understand different approaches and concepts needed across scales.

49. Danielsen F, Burgess ND, Jensen PM, Pirhofer-Walzl K: Environmental monitoring: the scale and speed of implementation varies according to the degree of peoples involvement. Journal of Applied Ecology 2010, 47:1166-1168.

50. Balvanera P, Siddique I, Dee L, Paquette A, Isbell F, Gonzalez A, Byrnes J, O'Connor MI, Hungate BA, Griffin JN: Linking Biodiversity and Ecosystem Services: Current Uncertainties and the Necessary Next Steps. BioScience 2014, 64:49-57.

51. Maass M, Balvanera P, Bourgeron P, Equihua M, Baudry J, Dick J, Forsius M, Halada L, Krauze K, Nakaoka $\mathrm{M}$ : Changes in biodiversity and trade-offs among ecosystem services, stakeholders, and components of well-being: the contribution of the International Long-Term Ecological Research network (ILTER) to Programme on Ecosystem Change and Society (PECS). Ecology and Society 2016, 21.

52. Rogers K, Luton R, Biggs H, Biggs RO, Blignaut S, Choles A, Palmer C, Tangwe P: Fostering complexity thinking in action research for change in social-ecological systems. Ecology and Society 2013, 18.

53. Muñoz-Erickson TA, Cutts BB: Structural dimensions of knowledge-action networks for sustainability. Current Opinion in Environmental Sustainability 2016, 18:56-64.

54. Václavík T, Langerwisch F, Cotter M, Fick J, Häuser I, Hotes S, Kamp J, Settele J, Spangenberg JH, Seppelt R: Investigating potential transferability of place-based research in land system science. Environmental Research Letters 2016, 11:095002.

55. Dearing JA, Wang R, Zhang K, Dyke JG, Haberl H, Hossain MS, Langdon PG, Lenton TM, Raworth K, Brown S: Safe and just operating spaces for regional social-ecological systems. Global Environmental Change 2014, 28:227-238.

56. Steffen W, Richardson K, Rockström J, Cornell SE, Fetzer I, Bennett EM, Biggs R, Carpenter SR, de Vries W, de Wit CA: Planetary boundaries: Guiding human development on a changing planet. Science 2015, 347:1259855.

*57. Kok MT, Kok K, Peterson GD, Hill R, Agard J, Carpenter SR: Biodiversity and ecosystem services require IPBES to take novel approach to scenarios. Sustainability Science 2017, 12:177-181.

Shows the relevance of and approaches needed to incorporate place-based scenarios into global science-policy initiatives

58. Wardropper CB, Gillon S, Mase AS, McKinney EA, Carpenter SR, Rissman AR: Local perspectives and global archetypes in scenario development. 2016.

59. Cundill G, Roux D, Parker J: Nurturing communities of practice for transdisciplinary research. Ecology and Society 2015, 20.

60. Brondizio ES, Le Tourneau F-M: Environmental governance for all. Science 2016, 352:1272-1273.

61. Abiodun BJ, Abba Omar S, Lennard C, Jack C: Using regional climate models to simulate extreme rainfall events in the Western Cape, South Africa. International Journal of Climatology 2016, 36:689-705.

62. Mattissek A: Forest politics in Thailand between global climate politics and local specificity. Geographische Zeitschrift 2014, 102:41-59. 